Portland State University

PDXScholar

6-6-1994

\title{
The Effects of Type of Child Care Arrangement and Satisfaction with Care on Employee Job Satisfaction and Absenteeism
}

Hanh Hong Nguyen

Portland State University

Follow this and additional works at: https://pdxscholar.library.pdx.edu/open_access_etds

Part of the Psychology Commons

Let us know how access to this document benefits you.

\section{Recommended Citation}

Nguyen, Hanh Hong, "The Effects of Type of Child Care Arrangement and Satisfaction with Care on Employee Job Satisfaction and Absenteeism" (1994). Dissertations and Theses. Paper 4784.

https://doi.org/10.15760/etd.6668

This Thesis is brought to you for free and open access. It has been accepted for inclusion in Dissertations and Theses by an authorized administrator of PDXScholar. Please contact us if we can make this document more accessible: pdxscholar@pdx.edu. 


\section{THESIS APPROVAL}

The abstract and thesis of Hanh Hong Nguyen for the Master of Science in Psychology were presented June 6, 1994, and accepted by the thesis committee and the department.

COMMITTEE APPROVALS:

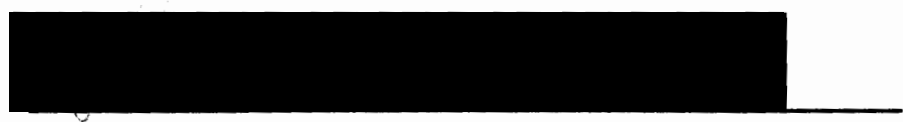

Leslie B. Hammer, Chair

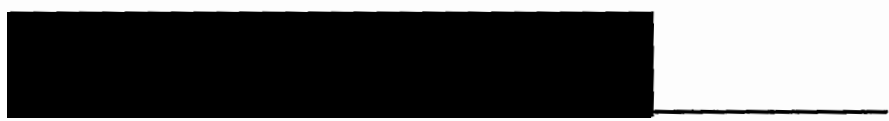

Dean Frost

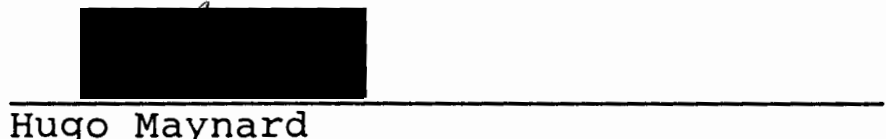

Hugo Maynard

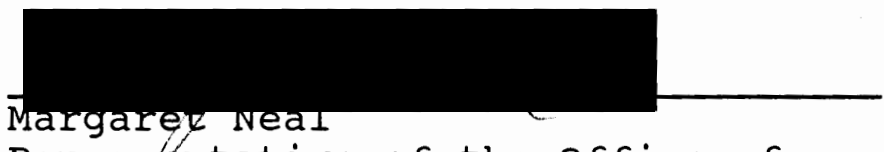
Represientative of the office of Graduate studies

DEPARTMENT APPROVAL:

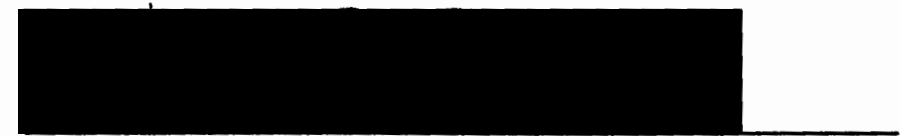

James A. Paulson, Chair Department of Psychology

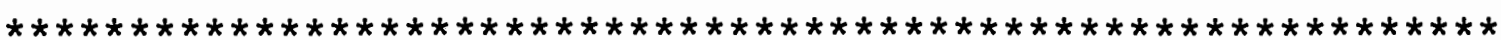

ACCEPTED FOR PORTLAND STATE UNIVERSITY BY THE LIBRARY

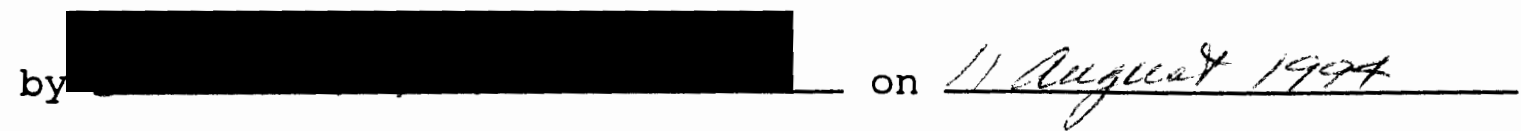




\begin{abstract}
An abstract of the thesis of Hanh Hong Nguyen for the Master of Science in Psychology presented June 6, 1994.

Title: The Effects of Type of Child Care Arrangement and Satisfaction with Care on Employee Job Satisfaction and Absenteeism.
\end{abstract}

This study examined the effects of different types of child care arrangements (i.e., care by relatives; care by nonrelatives; self-care by child; and care by day care centers) and satisfaction with care on employee absenteeism and job satisfaction. A 53\% response rate was obtained from a questionnaire administered to 501 classified staff employees at Portland state University. only responses from employees with children under the age of 18 living at home were used. Eighty-six employees met this selection criterion.

It was hypothesized that parents using self-care by child would have the highest absences, followed by parents using day care centers, followed by parents using care by nonrelatives, followed by parents using care by relatives. Second, it was hypothesized that parents using care by relatives would have the highest job 
satisfaction levels, followed by parents using care by nonrelatives, followed by parents using day care centers, followed by parents using self-care by child. Third, it was hypothesized that satisfaction with care would affect job satisfaction and absenteeism such that parents who were satisfied with their care arrangements would have higher job satisfaction and lower absenteeism. Fourth, it was hypothesized that there would be a significant difference between men and women on absenteeism such that women would have higher absences than men.

Hierarchical regression analyses revealed that employees using care by nonrelatives had significantly higher absences (during the last month and year) than those using care by relatives. In addition, employees using care by nonrelatives reported the highest number of absences on both measures of absenteeism. This study revealed that type of child care arrangement was not related to employee job satisfaction. The analyses also revealed that employees' satisfaction with care was related to absenteeism (during the last month), i.e., as parents' satisfaction with care increased, the number of absences reported decreased. Therefore, the first and third hypotheses were partially supported but the second and fourth hypotheses were not supported. The results of this study demonstrates that the types of child care arrangements that parents use are related to employee 
absenteeism but not job satisfaction. 
THE EFFECTS OF TYPE OF CHILD CARE ARRANGEMENT AND SATISFACTION WITH CARE ON EMPLOYEE JOB SATISFACTION AND ABSENTEEISM

by

HANH HONG NGUYEN

A thesis submitted in partial fulfillment of the requirements for the degree of

MASTER OF SCIENCE
in
PSYCHOLOGY

Portland state University 1994 
TABLE OF CONTENTS

LIST OF TABLES • • • • • • • • • • • • • . • • • IV CHAPTER

I INTRODUCTION • . . . . . . . . . . . . 1

History of Child Care Policies . . . . 4

Types of Child Care Arrangements . . . 12

Absenteeism and Child care . . . . 15

Job Satisfaction and Child Care . . . 18

Satisfaction with Child care:

Quality of care... . . . . . 20

Purpose of Present Study . . . . . . 22

II METHOD . . . . . . . . . . . . . . 26

Subjects . . . . . . . . . . . 26

Measures . . . . . . . . . . 26

Demographic Information

Type of Child Care Arrangement

Absenteeism

Job Satisfaction

Satisfaction with Child care

Arrangements

Procedure . . . . . . . . . . . 29

III RESULTS • . . . . . . . . . . . . . 30

Descriptive statistics . . . . . . 30

Demographic Characteristics 
Statistical Analyses . . . . . . 33

coding of Variables for Regression Analysis

Test of Hypothesis 1

Test of Hypothesis 2

Test of Hypothesis 3

Test of Hypothesis 4

IV DISCUSSION . . . . . . . . . . . . . 45

Limitations and Implications for

Future Research . . . . . . . 48

REFERENCES ................... 53

APPENDIX . . . . . . . . . . . . . . . . 57 


\section{LIST OF TABLES}

I Frequencies for Personal and Work

Characteristics of Respondents

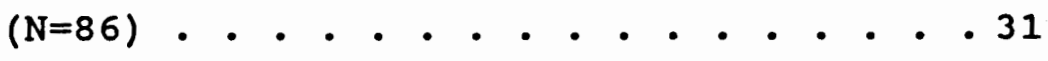

II Means and Standard Deviations for

Demographic Variables . . . . . . 32

III Parents' Mean Satisfaction with Care and

Frequencies for Parents' Satisfaction

and Dissatisfaction with Care . . . . 34

IV Mean Number of Absences (During the Last

Month) by Type of Care with Relative

Care as the Control Group in the

Regression Analysis $(\mathrm{N}=84)$. . . . . 37

$V$ Mean Number of Absences (During the Last

Year) by Type of Care with Relative

Care as the Control Group in the

Regression Analysis $(\mathrm{N}=73)$. . . . . 39

VI Results of Regression Analyses with Sex,

Type of Child Care Arrangement, and

Satisfaction with Care on Absenteeism

and Job Satisfaction . . . . . . . 43 
CHAPTER I

\section{INTRODUCTION}

The labor force participation of women has increased dramatically during the last several decades. The most dramatic change has been for women with preschool-aged children. In 1950, 34 percent of all women were working (Presser \& Baldwin, 1980), but only 13 percent of women with children under the age of six were participating in the work force (Petersen \& Massengill, 1988). By 1985, 44 percent of all women worked, but more than 50 percent of women with children under six years of age were employed (Petersen \& Massengill, 1988). Even though women work outside the home, they still perform the majority of child care tasks (Emlen \& Koren, 1984; Kossek, 1990; Northcott, 1983).

Parents that are employed must arrange for someone to care for their children if they are to work outside the home either full-time or part-time. Family day-care homes and care provided in the child's home by a relative or nonrelative are the most commonly used forms of care (Auerbach, 1988; Fernandez, 1986; Presser \& Baldwin, 1988; Ruderman, 1968; U.S. Bureau of the Census, 1982, 1983). However, as more women enter the labor force, 
this group of providers will decrease. How the young children of working parents are cared for while their parents are at work is not only an important issue for the social development of children, but it is also an important concern for parents, policy makers, and employers.

Some employers are responding to the demographic changes that have taken place, but most of their child care assistance programs provide only information and referrals (Goff, Mount, \& Jamison, 1990; Goldberg, Greenberger, Koch-Jones, O'Neil, \& Hamill, 1989). Few corporations actually fund on-site or nearby child care facilities (Friedman, 1987). Companies that sponsor child care programs believe that such involvement helps increase recruiting potential, morale, productivity, and quality of performance (Goff et al., 1990). Although a growing number of employers provide some form of child care support to their employees, few companies actually conduct a needs assessment prior to adopting these programs (Friedman, 1987). As a consequence, our understanding of the conditions related to types of child care needs of employees is still limited.

In this study, I will examine the effects of different types of child care arrangements and satisfaction with child care on work-related attitudes and behaviors of employees, such as job satisfaction and 
absenteeism. Some researchers have compared job satisfaction levels of employees in companies with child care programs to employees in companies without such programs, (Goldberg et al., 1989; Greenberger, Goldberg, Hamill, O'Neil, \& Payne, 1989; Youngblood \& Chamberscook, 1984), and mixed results were found. Other than comparing the job satisfaction levels of employees in companies with child care programs to those without child care programs, previous researchers have not specifically compared the job satisfaction levels of employees across different types of child care arrangements. In a few studies, employees' absenteeism rates were compared across different types of child care arrangements (Emlen \& Koren, 1984; Goff et al., 1990; Kossek, 1990; Milkovich \& Gomez, 1976), but these researchers did not examine employees' job satisfaction levels across the types of care. Researchers have found that the satisfaction of working parents with their child care arrangements is also related to their work attitudes. Goff et al. (1990) found that parents who were satisfied with their child care arrangements have less work/family conflict than parents who were not satisfied with their child care arrangements. These researchers also found that less work/family conflict was related to lower rates of absenteeism (Goff et al., 1990). But Goff et al.'s study did not examine the effects of child care satisfaction on 
employees' job satisfaction levels. Therefore, as part of this study I will also examine the effects of child care satisfaction on employees' job satisfaction levels and absenteeism rates.

In this study, I will specifically compare groups of employees categorized by the type of care they currently use. I will examine whether certain types of arrangements are more likely to cause parents to miss more days of work. I will examine if there is a relationship between the type of child care arrangement parents use and their job satisfaction levels. In this study, I will also examine the relationship between parents' satisfaction with their child care arrangements and their work attitudes and behaviors (i.e., job satisfaction and absenteeism).

\section{HISTORY OF CHILD CARE POLICIES}

The following historical review discusses the circumstances under which different types of child care programs have emerged in the United states. It also illustrates the development of our current image and supply of child care.

Day care historically existed to provide supervision of children of working parents, particularly low income and welfare mothers (Auerbach, 1988). In the 1830's, philanthropists developed the first day care program for 
infants (Auerbach, 1988; Greenblatt, 1977). These infant schools were intended as a charitable service to poor and immigrant families (Auerbach, 1988; Ruderman, 1968). Because many disadvantaged children were exposed to social and economic hardship, infant schools were developed because of the growing concern for these children's social welfare (Auerbach, 1988). Infant schools were mainly custodial, but also had educational goals for their participants (Auerbach, 1988).

Approximately at the same time infant schools were being organized, the United states government also became involved with child care on a small scale by providing some state support to day nurseries. The day nurseries were established as a response to the wave of immigration between 1815 and 1840 , to industrialization, and to the factory employment of women (Auerbach, 1988). Day nurseries, like infant schools, were also developed in response to the social welfare concerns of children (Auerbach, 1988; Greenblatt, 1977; Kerr, 1973; Ruderman, 1968). The first day nursery opened in 1838. Its primary goals were to prevent child neglect, to help reduce some of the hardships faced by working mothers, and also to preserve and strengthen the family (Auerbach, 1988; Greenblatt, 1977; Steinfels, 1973). By 1898, there were 175 day nurseries operating in the United states (Auerbach, 1988). 
As American industry and day nurseries grew, there were increasing pressures on poor mothers to work outside the home (Auerbach, 1988). During this period, there was an assumption that maternal employment was inappropriate for women and detrimental to families and children (Auerbach, 1988; Greenblatt, 1977). Day nurseries did not gain acceptance as an institution because their users were often stigmatized for being in a position of need (Auerbach, 1988; Kerr, 1973; Steinfels, 1973). Only children whose fathers were absent or disabled were accepted into day nurseries, and only under these circumstances was maternal employment justified by society (Auerbach, 1988).

social workers' claims that child care institutions provided only minimal care and allowed for the abuse of the children provoked the federal government to take action. The White House Conference on Children proposed programs in which children could be cared for in their own homes (Auerbach, 1988). In 1911, 40 states adopted a mother's pension law (Auerbach, 1988; Greenblatt, 1977). This pension was state-supported payments for wives and children of deceased, handicapped, insane, or imprisoned men. This law allowed women who would otherwise have to work to stay home to care for their children. The legislation for mothers led to a rapid decline of children's enrollment in day nurseries (Auerbach, 1988). 
Because of the decline in enrollment, day nurseries began accepting children of working parents even when the fathers were present or able bodied. For those mothers who chose to work, day nurseries were beginning to be viewed as an alternative to the pensions and also as a form of public relief (Auerbach, 1988).

The interest in child care began again during the periods of World War I and the Depression of 1932 (Fernandez, 1986). This interest in child care did not have anything to do with women's liberation or with women's career goals. During the Great Depression of the 1930's, President Roosevelt's Federal Emergency Relief Act, which later became the Works Progress Administration (WPA), provided federal funds to finance day nurseries and nursery schools (Auerbach, 1988; Fernandez, 1986). The primary goal of the Act was not to provide care for children, but to provide employment in these day care centers for the unemployed and to pull families off relief (Auerbach, 1988; Fernandez, 1986). In 1937, 40,000 children were participating in approximately 1,500-1,900 WPA child care programs (Auerbach, 1988). This was the first adoption by the federal government of the policy that the education of young children was a responsibility of the public (Kerr, 1973).

When women first began working during World War II, day care facilities were still limited in number because 
resistance to enlarging government's role in child care still remained (Auerbach, 1988). While men were away at war, the nation needed women to fill both women's and men's jobs. Many women joined the labor force and proved themselves competent workers in many areas that were previously restricted to men (Fernandez, 1986). But these jobs were temporary; the government only encouraged women to work because of a wartime emergency (Auerbach, 1988; Fernandez, 1986).

The dramatic growth in women's employment during the war indicated a need for some type of government action in child care (Auerbach, 1988). In 1941, Congress passed the Lanham Act which provided funds to set up child care centers in defense plants employing women during the World War II period (Auerbach, 1988). Communities were expected to provide 50 percent of the costs (Auerbach, 1988). When the war ended, popular support for day care declined and federal funding for day care facilities was withdrawn (Auerbach, 1988). Women were urged to return to their domestic work to make room in the labor force for the returning veterans (Auerbach, 1988; Fernandez, 1986). But surprisingly, many women still preferred to remain in the labor force, even though they were demoted from their wartime positions (Fernandez, 1986). Women were developing a new sense of independence and selfworth. 
Also during the period of World War II, private industry first became directly involved in providing child care because businessmen realized that it was necessary to attract and retain women during wartime (Auerbach, 1988; Fernandez, 1986). An example was the Kaiser Industries Corporation which employed 12,000 women in Oregon shipyards (Auerbach, 1988; Canon, 1978). The company developed on-site centers for mothers who did not have other child care arrangements available. Services included education, social work, nutrition, medical centers, and even hot take-home foods for its participants (Canon, 1978). While employers at Kaiser were viewed as admirable for their child care efforts, the company was also making profits (Auerbach, 1988). After the war ended, company child care centers closed when federal funding was withdrawn. Working women petitioned, demonstrated, lobbied their unions, and elected officials to try to keep child care centers open (Auerbach, 1988), but their efforts were useless and many left the labor force. The purpose of child care provided by the government and industries in wartime was to increase productivity, rather than to serve working women and their children (Auerbach, 1988).

During the $1950^{\prime} \mathrm{s}$, the nuclear family (father as breadwinner and mother as full-time housewife) became ingrained as ideal because of the propaganda glorifying 
the virtues of being a housewife (Auerbach, 1988). Although some mothers worked, there was little public or private support of child care services for them (Auerbach, 1988).

The 1960's brought back interests in child care. The government reinvested in day care centers for children whose parents would not or could not provide proper care for them (Auerbach, 1988). In 1964, Project Head start was created to provide an educational head start for economically disadvantaged children (Auerbach, 1988; Fernandez, 1986). The goal was to give poor and ghetto-dwelling, preschool-aged children an education that would prepare them to compete in public schools with their more advantaged peers (Auerbach, 1988; Fernandez, 1986). Even with criticisms concerning the success of the program, Head start had a positive effect on the public's attitude toward out-of-home child care (Auerbach, 1988).

The Civil Rights Act of 1964 began slowly to expand employment opportunities for women (Fernandez, 1986). The women's movement pressured Congress to develop systematic policies for dealing with child care and child development issues. In 1971, Congress attempted to pass the Comprehensive Development Act which would have provided services for welfare recipients, improved facilities for child care programs, and enriched the 
contents of child care programs (Fernandez, 1986). But the bill was vetoed by President Nixon because of pressures from organizations that still believed that a woman's place was in the home (Auerbach, 1988; Fernandez, 1986)

By 1975, despite pressures by women's groups, only limited resources were provided for the care of poor children, and tax deductions were allowed for widowed and divorced women who truly needed to work (Fernandez, 1986). In 1976, Congress replaced the tax deductions with a tax credit for child care expenses, and the income and marital status eligibility requirements were eliminated (Fernandez, 1986). The Economic Recovery Tax Act of 1981 raised the credit amount and established a sliding scale to provide greater relief for those considered low-income (Fernandez, 1986).

During the $1980^{\prime} \mathrm{s}$, government members recognized that family life style and demographics had changed over the last several decades, and that working mothers were here to stay (Auerbach, 1988). The Reagan Administration aimed at replacing government funding through increased pressure on private industries to provide child care benefits to their employees (Auerbach, 1988; Fernandez, 1986). Employer-supported child care came with the creation of the Dependent Care Assistance Plan which enabled employers to offer child care as a tax-free 
benefit to employees (Auerbach, 1988). As more and more women entered the labor force, tax laws provided tax benefits to employers who offered child care assistance implemented to address the problems of turnover and absenteeism (Fernandez, 1986). Today, tax laws also allow many employers to offer flexible benefit packages in which child care assistance can be one option (Auerbach, 1988).

\section{TYPES OF CHILD CARE ARRANGEMENTS}

As a result of the changes in women's work force participation in the past several decades, there has been a shift away from in-home child care to care outside the home (U.S. Bureau of the Census, 1982). The most popular types of child care arrangements used by parents are: care in the child's home by the mother, father, relative, or nonrelative; care in another home by a relative or nonrelative; child cares for himself or herself; mother or father cares for the child while she or he is working; group care centers which include day care centers, nursery schools, preschools, and kindergartens (Auerbach, 1988; Fernandez, 1986; Presser \& Baldwin, 1988; Ruderman, 1968 ; U.S. Bureau of the Census, 1982, 1983); and employer-supported child care (Auerbach, 1988, 1990; Petersen \& Massengill, 1988).

This last type of child care arrangement, employer- 
supported child care, is defined as "a situation in which an employer, group of employers, or a labor union takes some initiative in meeting employees' child care needs and bears some or all of the cost" (Auerbach, 1988, p. 65). There are four categories of employer-supported child care programs: (1) direct services - which include provision of actual space, such as on-site or off-site day care centers, family day care networks, after school programs, and summer camps; (2) information - which includes information and referral services, employee assistance programs, and parent education; (3) financial assistance - which includes vendor arrangements, vouchers, flexible benefits, and corporate contributions to child care agencies and programs; and (4) alternative work schedules - which include flextime, part time, job sharing, and flexible parental leave policies (Auerbach, 1988, 1990; Kossek, 1990; Petersen \& Massengill, 1988).

Different types of child care arrangements place different demands on mothers and fathers. Cohen and Wills (1985) argue that family support can help buffer employees from life stress. Employees who are fortunate enough to have relatives providing child care have extra social support compared to those employees who must use care provided by nonrelatives (Kossek, 1990). This is especially true given the recent attention by the media to child abuse by caregivers and the detrimental effects 
on children of poor quality care centers (Kossek, 1990). Kossek (1990) investigated the degree to which employee background variables (e.g., gender, household employment configuration, dependent's care profile, managerial status, and use of family care arrangements) were related to child care problems, attitudes toward managing work and child care responsibilities, and the absence behavior of 198 employees who had dependents under age 12. Kossek found that users of child care not provided by adult relatives experience significantly more problems with their child care arrangement than families with a parent at home. Employees using a combination of family and nonfamily care experienced significantly less problems with aspects of their child care arrangements than those using only nonfamily care, but these mixed care users experience more problems than those using total familial care (Kossek, 1990). For the purpose of the present study, type of child care will be defined using the following four categories: (1) child care provided by spouse or other adult relatives, (2) child care provided by nonrelatives in a non-day care setting, (3) child cares for himself or herself, and (4) child care provided by group care centers or family day care centers. 


\section{ABSENTEEISM AND CHILD CARE}

Many studies have found that child care problems are related to employees' attitudes and behaviors toward work (Auerbach, 1990; Emlen \& Koren, 1984; Goff et al., 1990; Goldberg et al., 1989; Kossek, 1990; Miller, 1984; Presser \& Baldwin, 1980). There is some evidence that onsite employer-sponsored child care centers may reduce employee absenteeism, but the results are mixed. Youngblood and Chambers-cook (1984) examined three companies in the textile/apparel industry in North and South Carolina to evaluate the impact of an employerprovided, in-house child care facility on employee attitudes and behavior. The authors found that an onsite child care facility was associated with lower absenteeism and turnover rates for parents using the facility compared with nonusers.

Milkovich and Gomez (1976) compared parents that used a day care center as care for their children to those that did not use a care center. In their study, they found that monthly turnover and absenteeism rates were lower for the parents of day care users than nonusers. They also found parents who did not enroll their young children in day care showed greater variability in their absenteeism rates (Milkovich \& Gomez, 1976).

studies examining demographic variables that are 
significantly related to child care problems and productivity generally found the employee's gender was the most important factor (Klein, 1986). Most studies on the relationship between child care and absenteeism demonstrates that women have higher absenteeism levels than men. In two studies, women were found to be absent from work more than men because of illness (EnglanderGolden \& Barton, 1983; Northcott, 1983). The greatest gender differences in absence from work were found between the ages of 25-34 (Hedges, 1977). Interestingly, this is the prime child bearing age for women. Child care responsibilities may account for women's greater absenteeism than men in this age group. Among parents, mothers have significantly higher absenteeism rates than fathers because of child care responsibilities (Englander-Golden \& Barton, 1983; Northcott, 1983). Married women took more sick leave than single women (Miller, 1984) and single women were found to have the same absenteeism rates as single men (Englander-Golden \& Barton 1983; Hedges, 1977). Even with the increasing trend toward egalitarianism, when both parents were employed, women were still more likely to provide care for their sick child and to handle their children's dentist and doctor appointments (Englander-Golden \& Barton, 1983; Fernandez, 1986; Northcott, 1983). Taking care of a sick child or taking a child to a doctor or 
dentist is not usually a compensable absence. To employers, therefore, a parent usually reports such an absence as personal illness rather than child care responsibilities (Englander-Golden \& Barton, 1983). Emlen and Koren (1984) compared the absenteeism rates of 2,430 parents with children under age 12 by the type of child care used. They found that female employees whose children were in out-of-home care, and especially those relying on care by a child, experienced the highest absenteeism rates. Fathers also missed as many days per year as mothers when the arrangement was care by a child (Emlen \& Koren, 1984). Findings indicate that male employees whose children remained at home with a spouse or with another adult have roughly the same absenteeism rates as male employees without children (Emlen \& Koren, 1984).

As mentioned earlier, men and women strongly support an egalitarian sex role division of labor, especially regarding the issue of child care (Northcott, 1983). However, in practice, their behavior reflects the traditional division of labor: it was the mother who was more likely to stay home to care for the sick child when both parents worked (Emlen \& Koren, 1984; EnglanderGolden \& Barton, 1983; Northcott, 1983). This was true whether she worked full-time or part-time. Even in one case where the mother worked full-time and the father 
worked part-time, it was still the mother who stayed home with their sick child (Northcott, 1983). Therefore, in families where both parents work, women still appear to carry the majority of child care responsibilities.

In summary, research on child care and absenteeism has found that absence rates were lower for parents of day care users than nonusers (Milkovich \& Gomez, 1976). On-site child care facilities were associated with lower absenteeism and turnover rates for employees (Youngblood \& Chambers-Cook, 1984). Women employees whose children took care of themselves or were in out-of-home care were found to have the highest absenteeism rates compared to parents that used other types of care (Emlen \& Koren, 1984). Fathers missed as many days as mothers when their children cared for themselves (Emlen \& Koren, 1984). And male employees whose children remained at home with a spouse or with another adult have approximately the same absenteeism rates as male employees without children (Emlen \& Koren, 1984).

\section{JOB SATISFACTION AND CHILD CARE}

Many employers claim that when they provide child care programs, the organization benefits through lower absenteeism and turnover rates, improved employee attitudes toward the organization and the job, higher morale, and more successful recruitment (Petersen \& 
Massengill, 1988; Zippo, 1980), favorable publicity, and improved community relations (Zippo, 1980). Employees' job satisfaction levels have been compared among employees with or without company-sponsored child care programs in several studies (Goldberg et al., 1989; Greenberger et al., 1989; Youngblood \& Chambers-cook, 1984). Youngblood and Chambers-Cook (1984) found that higher job satisfaction levels were associated with onsite child care facilities that were provided by employers. Greenberger et al. (1989) surveyed married men, married women, and single women with preschool-aged children on issues concerning social support from coworkers and supervisors, utilization of family-responsive benefits and policies, readiness to leave the employer for additional benefits, job satisfaction, organizational commitment, role strain, and health symptoms. Married men, married women, and single women who were least satisfied with their company's child care benefits, work schedules, and related benefits expressed lower levels of commitment or loyalty to their firms (Greenberger et al., 1989). Greenberger et al. also found that single and married mothers had lower job satisfaction levels than married fathers.

The U.S. Department of Labor, Employment and Training Division (1977) reported that women with young children had lower job satisfaction levels than those 
without young children. In addition, Kossek (1990) found that parents who were experiencing problems with child care arrangements had significantly less favorable attitudes toward their work and child care responsibilities. Many women workers indicated that they often considered quitting their jobs because of child care problems and that such difficulties create problems at work for them (Kossek, 1990). For mothers who prefer to work, the availability of child care allows them to invest more time and energy into their work (Ross \& Mirowsky, 1988) .

In summary, research has found that on-site child care facilities were associated with higher job satisfaction levels for employees (Youngblood \& ChambersCook, 1984). Single and married mothers were found to have lower job satisfaction levels than married fathers (Greenberger et al., 1989). Studies have also found that married men, married women, and single women who were least satisfied with their child care related benefits expressed lower levels of commitment to their companies (Greenberger et al., 1989).

SATISFACTION WITH CHILD CARE: QUALITY OF CARE

Emlen, Koren, and Yoakum's (1990) surveys of the work force of 15 employers of Lane county, oregon, found that 47 percent of mothers and 26 percent of fathers with 
children under 12 were dissatisfied with their current type of child care arrangement. Parents' dissatisfaction levels were higher when the children were looking after themselves, were with an older sibling, or were with a babysitter under 18 years of age (Emlen et al., 1990). However, parents' judgments of satisfaction with their types of child care arrangements are complex. Satisfaction with care includes aspects of care, such as convenience, costs, the family's relationship with the caregiver, parents' perceptions of the quality of care (Neal, Chapman, Ingersoll-Dayton, \& Emlen, 1993; Powell \& Bollin, 1992), hours available for care, location of care, location of care with respect to work, physical appearance of the care environment, the center's curriculum, and the quality of care given to the children (Fernandez, 1986). There are also variations in the quality of care provided within different types of care (Neal et al., 1993). Professional motivations, specific training, and licensing were found to be associated with quality of care among family day-care providers (Pence \& Goelman, 1991). Quality of care in child care centers was associated with group size in classrooms, adult-child ratio, and quality of staff (Ruopp, Travers, Glantz, \& Coelen, 1979).

There is empirical support for the idea that parents' satisfaction with their child care arrangements 
is related to their work attitudes. Goff et al. (1990) examined the relations among employer-sponsored child care, work/family conflict and absenteeism. The results of Goff et al.'s study indicated that supervisor support and parents' satisfaction with their child care arrangement, regardless of location, was related to less work/family conflict, which then lead to lower absenteeism rates.

Researchers have also found a positive correlation between child care satisfaction and job satisfaction (Goldberg et al., 1989; Harrell \& Ridley, 1975). Goldberg et al. (1989) examined the appeal of various corporate-sponsored benefits and policies that would enable parents to coordinate employment and child care for 321 parents. Goldberg et al. found that employees' satisfaction with their child-care-related corporate benefits and policies was positively related to the employees' job satisfaction and organizational commitment.

\section{PURPOSE OF PRESENT STUDY}

Previous research has specifically focused on comparing the different types of child care arrangements and their effects on absenteeism, but not on job satisfaction. The purpose of this study is to investigate the type of child care arrangement parents 
use (i.e., care provided by a spouse or other adult relatives; care by nonrelatives; child cares for himself/herself; and care provided by group care centers or family day care centers) and the degree to which it is related to their work-related attitudes and behaviors, specifically job satisfaction and absenteeism. The purpose is also to examine the effects of parents' satisfaction with their current type of child care arrangement on job satisfaction and absenteeism.

Parents using care arrangements provided by a spouse or relative are assumed to be worried less about child abuse (Lande, Scarr, \& Gunzenhauser, 1989), provider turnover, or poor quality of care, than parents using other types of care (Kossek, 1990). Therefore, it is speculated that these parents will have fewer child care problems because they have a greater trust of a family member than of a nonrelative caregiver. It is assumed that parents using child care arrangements provided by a spouse or relative do not have as much worry about the safety and security of their children compared to working parents using other types of child care arrangements. Thus, absences will be low and job satisfaction will be high when child care is done by relatives.

It is also suggested that parents will have the greatest amount of child care problems when using care arrangements in which children care for themselves 
because they worry about the safety of their children and feel guilty for leaving their young children home alone while they are at work (Emlen \& Koren, 1984). It is assumed that parents with more child care problems will have greater negative influences on their work-related outcomes, specifically lower job satisfaction levels and higher absenteeism rates.

Parents using care by nonrelatives and day care centers are assumed to worry more about provider turnover problems (Kossek, 1990). For example, it is difficult to find a reliable and dependable babysitter when needed. It is also difficult to arrange for a babysitter on a daily basis. Day care centers also have disadvantages: they may not accommodate some parents' work schedules or ill children (Neal et al., 1993). Therefore, these parents are required to make alternative arrangements, which sometimes can be difficult, when their children become ill.

Therefore, it is hypothesized $\left(\mathrm{H}_{1}\right)$ that parents using child care arrangements in which the child cares for himself/herself will have the highest absence rates, followed by parents using care centers, followed by those using care by nonrelatives, followed by those using care provided by a spouse or relative. Second, it is also hypothesized $\left(\mathrm{H}_{2}\right)$ that parents using care by a spouse or relative will have the highest job satisfaction levels, 
followed by those using care by nonrelatives, followed by parents using care centers, followed by parents using care by child. Third, it is hypothesized $\left(\mathrm{H}_{3}\right)$ that satisfaction with care will affect job satisfaction and absenteeism such that parents who are satisfied with their child care arrangements will have higher levels of job satisfaction and lower absenteeism rates. Fourth, it is hypothesized $\left(\mathrm{H}_{4}\right)$ that there will also be significant differences between men and women on absenteeism such that women will have higher absence rates than men. 
CHAPTER II

METHOD

SUBJECTS

All classified staff members at Portland State University were asked to serve as voluntary participants for this study. Of the 501 surveys mailed to employees, $53 \%(\mathrm{~N}=265)$ were returned. The criterion for the selection of subjects was that they must be employees with children under the age 18 living at home. Eightysix employees met the selection criterion (86 of 265 , or $32 \%)$.

\section{MEASURES}

A paper and pencil questionnaire was administered (See Appendix A) at Portland State University. The questionnaire took approximately 30 minutes to complete. Participants were told they would remain anonymous. The questionnaire included the following measurements:

\section{Demographic Information}

Participants were asked to report their sex, age, marital status, total number of children, ages of children under 18, current occupation, and weekly hours 
worked.

\section{Type of Child Care Arrangement}

Participants were given choices of four types of child care arrangements plus a not applicable category. Parents were asked to indicate the type of child care arrangement(s) they currently use for their children by reporting the age(s) of the children next to the type(s) of care.

It is important to note that many parents may have children attending the Helen Gordon Child Development Center located at Portland state University. The center is an on-site day care center provided for children of Portland State University faculty, staff, and students.

\section{Absenteeism}

Work absence due to child care responsibilities was measured using employees' self-reports. Questions were asked about four kinds of absenteeism as categorized by Emlen and Koren (1984): days missed (missing at least 4 hours of work-time) excluding holidays, times late, times left early, and times interrupted while at work due to child care responsibilities during the last month. Parents were also asked to report absenteeism during the past year. Thus, two measures of absence were used for this study (i.e., reports of absences during the last month and year). The intent of this study was to use 
absence behavior as an example of negative work behavior which stems from the type of child care arrangement parents use.

\section{Job Satisfaction}

Job satisfaction was measured using the Job Descriptive Index (JDI) checklist (Smith, Kendall, \& Hulin, 1969). The JDI measures satisfaction with work, pay, promotions, supervision, and co-workers. Only the overall Job Satisfaction score (summing all the 72 items) was examined in this study. The coefficient alpha of internal reliability for this measure exceeded .90 in each of the samples from the Bowling Green state University data pool with $N>100$ (Balzer \& Smith, 1990).

\section{Satisfaction with Child care Arrangements}

Satisfaction with present child care arrangements was measured using 10 items written by Fernandez (1986) which asked parents to indicate their level of satisfaction with aspects of care such as cost, hours available, location, physical appearance, and quality of care. Respondents used a 4-point Likert-type scale ( $1=$ not at all satisfied; 4 = very satisfied). subjects were asked to report satisfaction with each type of care they used. The internal reliability for this scale is $r=.85$ (Goff et. al, 1990). 
PROCEDURE

Questionnaires were distributed to all classified staff members at Portland state University through campus mail. Employees' names were obtained from the Institutional Research and Planning office at Portland state University. A cover letter asked participants to complete the questionnaires anonymously and to return them by the deadline date. Questionnaires were returned to Portland State University's Psychology Department in self-addressed envelopes provided by the researcher. 
CHAPTER III

RESULTS

DESCRIPTIVE STATISTICS

\section{Demographic Characteristics}

The descriptive statistics are shown in Tables $I$ and II. Descriptive statistics revealed that $80 \%$ of the subjects were females $(\mathrm{N}=69)$ and $20 \%$ were males $(\mathrm{N}=17)$. Sixty-five percent were married and $35 \%$ were not married. Nineteen percent of respondents were in professional occupations, $56 \%$ were secretarial/clerical, $17 \%$ were technical/paraprofessional, and $8 \%$ were in other occupations. The average age of subjects was 40 years. Subjects had an average of 2 children and the average age of child was 9 years. Subjects worked an average of 38 hours per week.

Twenty-five percent $(N=21)$ of subjects used care by a spouse or other adult relative as their primary type of child care, $47 \%(\mathrm{~N}=39)$ had children take care of themselves, $14 \%(\mathrm{~N}=12)$ used care by nonrelatives in a non-day care setting, and $14 \%(\mathrm{~N}=12)$ used day care centers for their children. Primary type of care was the type of care used most frequently and was based on the 
TABLE I

FREQUENCIES FOR PERSONAL AND WORK CHARACTERISTICS OF RESPONDENTS $(\mathrm{N}=86)$

$\underline{\mathrm{n}}$

Percent

$\operatorname{sex}$

Male

Marital status

Married

Non-married

Occupation

Professional
Female

16

48

15

Secretarial/Clerical

Technical/Paraprofessional

other
7

65.1

34.9

30

19.8

80.2

17

69

56

18.6

55.8

17.4

8.2 
TABLE II

MEANS AND STANDARD DEVIATIONS FOR DEMOGRAPHIC VARIABLES

$\underline{n} \quad \underline{M} \quad \underline{S D}$

Age

85

39.58

7.36

Number of children

86

2.12

1.15

Age of children

132

9.49

5.07 under 18

Weekly hours worked

86

38.37

8.24 
number of hours reported. Of the $25 \%$ of subjects who used care provided by a spouse or relative, $40 \%$ ( $\mathrm{N}=8$ ) used care by spouse or partner, $10 \%(\mathrm{~N}=2)$ used care by an older sibling over age $18,40 \%(\mathrm{~N}=8)$ used care by grandparent, and $10 \%(\mathrm{~N}=2)$ used care by some other adult relative. Although parents tended to be satisfied with their child care arrangements, similar to Emlen et al.'s (1990) findings, parents' dissatisfaction levels were higher when children were looking after themselves (see Table III).

STATISTICAL ANALYSES

\section{Coding of Variables for Regression Analysis}

Dummy coding was used to code the four types of child care arrangements that parents used for their children (care by relatives, care by child himself/herself, care by nonrelatives, and care by day care centers). Demographic variables (age, number of children, and weekly hours worked) were entered as continuous variables. The variables absenteeism, job satisfaction, and satisfaction with care were also entered as continuous variables.

Hierarchical regression analyses were used to assess the relationships between sex, the type of child care arrangement, and satisfaction with care and the dependent variables (absenteeism and job satisfaction). A t-test 
TABLE III

PARENTS' MEAN SATISFACTION WITH CARE AND FREQUENCIES FOR PARENTS' SATISFACTION AND DISSATISFACTION WITH CARE

\begin{tabular}{lllllll} 
Type of Care & $\underline{\mathrm{n}}$ & $\underline{\mathrm{M}}$ & $\begin{array}{c}\text { Percent } \\
\text { Satisfied }\end{array}$ & $\begin{array}{c}\text { Percent } \\
\text { Dissatisfied }\end{array}$ \\
\hline Self-care & 39 & 3.2265 & 71.79 & 28 & 28.21 & 11 \\
Day care & 12 & 3.2939 & 91.67 & 11 & 8.33 & 1 \\
Nonrelative & 12 & 3.2500 & 91.67 & 11 & 8.33 & 1 \\
Relative & 21 & 3.6262 & 90.48 & 19 & 9.52 & 2 \\
\hline
\end{tabular}

Note. 1 = not at all satisfied, 4 = very satisfied. 
was used to examine the difference between males and females on absenteeism.

\section{Test of Hypothesis 1}

It was hypothesized that parents using child care arrangements in which the child cares for himself/herself would have the highest absence rates, followed by parents using care centers, followed by those using care by nonrelatives, followed by those using care provided by a spouse or relative. The first regression analysis (Regression Equation 1) was conducted to assess the amount of variance accounted for in absenteeism (during the last month) by sex, the type of child care arrangement, and satisfaction with care. First, the variable "sex" was entered into Regression Equation 1. The amount of variance accounted for in absenteeism by sex was $0 \%, R^{2}=.00$, and did not meet the $\underline{p}<.05$ criterion, thus, was not significant. Second, the variable "type of child care arrangement" was added to Regression Equation 1. The amount of variance accounted for in absenteeism by type of child care arrangement was 7\%, $\Delta \mathrm{R}^{2}=.07$, and was also not significant. Third, the variable "satisfaction with care" was added to Regression Equation 1. The amount of variance accounted for in absenteeism by satisfaction with care was $15 \%, \Delta \mathbf{R}^{2}=.15$, $\underline{p}<.0035$. The overall amount of variance accounted for in absenteeism (during the last month) by sex, type of 
care, and satisfaction with care was $22 \%, R^{2}=.22$, $\underline{F}(5,70)=3.90, \underline{p}<.0035$.

Since dummy coding was used to code the four types of care in the regression analysis, dummy coding effects were examined. Relative care was coded as the control group because parents using this type of care were expected to have the lowest absence rates. The analysis found that only parents using care by nonrelatives had significantly higher absences than those using care by relatives, beta $=3.06, \underline{t}=2.37, \underline{p}<.0200$ (see Table IV). Parents using care by child and day care centers were not significantly different from parents using relative care. Comparison of means revealed that parents using care by nonrelatives had the highest number of absences $(\underline{M}=3.58)$, followed by those using day care centers $(\underline{M}=1.42)$, followed by those using care by child himself/herself $(\underline{M}=1.31)$, and those using care by relatives had the lowest absence rates $(\underline{M}=.57)$. Thus, this hypothesis was partially supported in that parents using care by relatives were found to have the lowest absence rates and those using care by centers were found to have the second highest absenteeism rates. However, parents using care by nonrelatives had the highest number of absences and those using care by child himself/herself had the third highest number of absences.

A second regression analysis (Regression Equation 2) 
TABLE IV

MEAN NUMBER OF ABSENCES (DURING THE LAST MONTH) BY TYPE OF CARE WITH RELATIVE CARE AS THE CONTROL GROUP IN THE REGRESSION ANALYSIS $(\mathrm{N}=84)$

\begin{tabular}{llllll} 
Type of Care & $\underline{\mathrm{n}}$ & $\underline{\mathrm{M}}$ & $\underline{\text { Beta }}$ & $\underline{\text { t-value }}$ & $\underline{\mathrm{P} \text { value }}$ \\
\hline & & & & & \\
Self-care & 39 & 1.3077 & 0.991 & 1.034 & $\mathrm{n} . \mathrm{s}$. \\
Day care & 12 & 1.4167 & 0.838 & 0.652 & $\mathrm{n} . \mathrm{s}$. \\
Nonrelative & 12 & 3.5833 & 3.055 & 2.374 & $<.0200$ \\
Relative & 21 & 0.5714 & & & \\
\hline
\end{tabular}

Note. n.s. = not significant. 
was performed to assess the amount of variance accounted for in absenteeism (during the last year) by sex, type of child care arrangement, and satisfaction with care. Again, dummy coding was used for the analysis, relative care was the control group. First, the variable "sex" was entered into Regression Equation 2. The amount of variance accounted for in absenteeism by sex was $0 \%$, $R^{2}=.00$, and did not meet the $\underline{p}<.05$ criterion, thus, was not significant. Second, the variable "type of child care arrangement" was added to Regression Equation 2. The amount of variance accounted for in absenteeism by type of child care arrangement was $10 \%, \Delta R^{2}=.10$, and was not significant. Third, the variable "satisfaction with care" was added to Regression Equation 2. The amount of variance accounted for in absenteeism by satisfaction with care was $5 \%, \Delta R^{2}=.05$, and also was not significant. The overall amount of variance accounted for in absenteeism (during the last year) by sex, type of care, and satisfaction with care was 16\%, $\mathrm{R}^{2}=.16$, and was not significant.

Analysis of the dummy coding effects revealed that parents using care by nonrelatives had significantly higher absences than those using care by relatives, beta $=9.34, \underline{t}=2.56, \underline{p}<.0125$ (see Table V). Parents using care by child and day care centers were not significantly different from parents using relative care. 
TABLE V

MEAN NUMBER OF ABSENCES (DURING THE LAST YEAR) BY TYPE OF CARE WITH RELATIVE CARE AS THE CONTROL GROUP IN THE REGRESSION ANALYSIS $(\mathrm{N}=73)$

\begin{tabular}{lrrrrl} 
Type of Care & $\underline{\mathrm{n}}$ & $\underline{\mathrm{M}}$ & $\underline{\text { Beta }}$ & $\underline{\text { t-value }}$ & $\underline{\text { v value }}$ \\
\hline & & & & & \\
Self-care & 34 & 10.618 & 2.784 & 1.091 & $\mathrm{n} . \mathrm{s}$. \\
Day care & 10 & 7.200 & -0.592 & -0.168 & $\mathrm{n} . \mathrm{s}$. \\
Nonrelative & 9 & 17.111 & 9.338 & 2.564 & $<.0125$ \\
& & & & & \\
Relative & 20 & 7.750 & & & \\
\hline
\end{tabular}


Comparison of means revealed that parents using care by nonrelatives had the highest number of absences $(\underline{M}=17.11)$, followed by those using care by child himself/herself $(\underline{M}=10.62)$, followed by those using care by relatives $(\underline{M}=7.75)$, followed by parents using day care centers $(\underline{M}=7.20)$. Thus hypothesis 1 was partially supported when the variable absenteeism (during the last year) was examined in that parents using care by relatives were found to have the lower absence rates than those using care by nonrelatives and care by child. However, parents using care by centers had the lowest number of absences compared to those using other types of care.

\section{Test of Hypothesis 2}

It was also hypothesized that parents using care by a spouse or relative would have the highest job satisfaction levels, followed by those using care by nonrelatives, followed by parents using care centers, followed by parents using care by child. A third regression analysis (Regression Equation 3) was conducted to assess the amount of variance accounted for in job satisfaction by sex, the type of child care arrangement, and satisfaction with care. Dummy coding was used to code the four types of care, relative care was used as the control group. First, the variable "sex" was entered into Regression Equation 3. The amount of variance 
accounted for in job satisfaction by sex was $2 \%$, $\mathrm{R}^{2}=.02$, and did not meet the $\mathrm{p}<.05$ criterion, thus, was not significant. Second, the variable "type of child care arrangement" was added to Regression Equation 3 . The amount of variance accounted for in job satisfaction by type of child care arrangement was $1 \%, \Delta R^{2}=.01$, and was not significant. Third, the variable "satisfaction with care" was added to Regression Equation 3. The amount of variance accounted for in job satisfaction by satisfaction with care was $1 \%, \Delta R^{2}=.01$, and was also not significant. The overall amount of variance accounted for in job satisfaction by sex, type of care, and satisfaction with care was $4 \%, R^{2}=.04$, and was not significant.

Analysis of the dummy coding effects did not reveal significant differences across the four types of care on job satisfaction levels. Therefore, hypothesis 2 was not supported.

\section{Test of Hypothesis 3}

It was hypothesized that satisfaction with care would affect job satisfaction and absenteeism such that parents who were satisfied with their child care arrangements would have higher levels of job satisfaction and lower absenteeism rates. When the variable "satisfaction with care" was added to Regression Equations 1, 2, and 3, the increase in $\mathrm{R}^{2}$ in Regression 
Equation 1 due to satisfaction with care was significant, $\Delta \mathrm{R}^{2}=.15, \underline{F}(5,70)=3.902, \underline{\underline{Q}}<.0035$ (see Table VI). However, the increase in $R^{2}$ in Regression Equations 2 and 3 due to satisfaction with care was not significant, $\Delta R^{2}=.05, \Delta R^{2}=.01$, respectively. Therefore, the hypothesis that parents who are satisfied with their type of child care arrangement will have higher job satisfaction and lower absenteeism was partially confirmed.

\section{Test of Hypothesis 4}

It was also hypothesized that there would be significant differences between men and women on the two measures of absenteeism (absences during the last month and year), such that women will have higher absences than men.

A t-test was performed to examine if there were significant differences between males and females on the two types of absenteeism. There were no significant differences between males and females on either measure. Therefore, hypothesis 4 was not supported.

A follow-up analysis was conducted to determine if there was a significant difference between men and women on item \#22 which asked, "In your household, who spends the most time on tasks related to child rearing?" The analysis indicated that women spend significantly more time on tasks related to child rearing than men, 
TABLE VI

RESULTS OF REGRESSION ANALYSES WITH SEX, TYPE OF CHILD CARE ARRANGEMENT, AND SATISFACTION WITH CARE ON ABSENTEEISM AND JOB SATISFACTION

$\underline{\Delta R^{2}} \quad \underline{F-V a l u e *} \quad \underline{P \text { Value }}$

Regression Equation 1

$\begin{array}{llll}\text { by Sex } & .0009 & 0.226 & \mathrm{n} . \mathrm{s} . \\ \text { by Type of Care } & .0681 & 1.483 & \mathrm{n} . \mathrm{s} . \\ \text { by Satisfaction } & .1490 & 3.902 & .0035 \\ \quad \text { with Care } & & & \end{array}$

Regression Equation 2

$\begin{array}{cccc}\text { by Sex } & .0032 & 0.741 & \text { n.s. } \\ \text { by Type of Care } & .1000 & 1.985 & \text { n.s. } \\ \text { by Satisfaction } & .0541 & 2.240 & \text { n.s. } \\ \text { with Care } & & & \end{array}$

Regression Equation 3

$\begin{array}{cccc}\text { by Sex } & .0221 & 1.719 & \mathrm{n} . \mathrm{s} . \\ \text { by Type of Care } & .0142 & 0.679 & \mathrm{n} . \mathrm{s} . \\ \text { by Satisfaction } & .0065 & 0.590 & \mathrm{n} . \mathrm{s} . \\ \quad \text { with Care } & & & \end{array}$

*Note. F-value is for equation after each step's variable is entered. 
$\underline{t}(83)=-4.90, \underline{p}<.0000$. Men reported that "my spouse/partner and I spend about equal time on tasks related to child rearing" $(\underline{M}=3.59)$. Women reported that "I spend slightly more time on tasks related to child rearing" $(\underline{M}=5.41)$. 
CHAPTER IV

DISCUSSION

The purpose of this study was to examine the effects of type of child care arrangements and satisfaction with care on work-related outcomes (i.e., absenteeism and job satisfaction). The regression analyses showed that employees using care by nonrelatives had significantly higher absences (during the last month and year) than those using care by relatives. Regression analyses revealed type of care was not significantly related to job satisfaction.

When the variable absenteeism (during the last month) was examined, employees using care by nonrelatives reported the highest number of absences, followed by those using day care centers, followed by those using self-care by child, and those using care by relatives reported the lowest number of absences. As mentioned earlier, when the variable absenteeism (during the last year) was examined, the results also revealed that parents using care by nonrelatives had significantly higher absences than those using care by relatives. Employees using care by nonrelatives reported the highest number of absences, followed by those using self-care by 
child, followed by those using care by relatives, and those using care by centers reported the lowest number of absences during the last year.

As mentioned earlier in the study, many employers claim that when they provide child care programs, their organization benefits through lower absenteeism and turnover rates, improved employee attitudes toward the organization and the job, higher morale, and more successful recruitment (Petersen \& Massengill, 1988; Zippo, 1980), favorable publicity, and improved community relations (zippo, 1980). Contrary to the hypothesis that parents using self-care by child would have the highest absences, the regression analyses revealed that parents using nonrelative care had significantly higher absences (during the last month and year) than those using relative care. This effect may have been due to the media's focus on child abuse by caregivers and the detrimental effects on children of poor quality care centers (Kossek, 1990). Parents may have difficulty leaving their child with someone who is not a licensed or an experienced caregiver. Also, parents using care by nonrelatives may experience provider turnover problems (Kossek, 1990). It is difficult to arrange for reliable and dependable care when needed. Similar to Milkovich and Gomez's (1976) research finding on child care and absenteeism, this study also found that absence rates 
(during the last year) were lower for parents using day care than parents using other forms of care. Contrary to Emlen and Koren's (1984) study, parents using self-care by child in this study did not have the highest absence rates compared to parents that used other types of care. The hypothesis that parents using care by a spouse or relative would have the highest job satisfaction levels, followed by those using care by nonrelatives, followed by parents using care centers, followed by parent using self-care by child was not supported. This study found that parents did not differ significantly on their job satisfaction levels, regardless of the type of child care arrangement they used for their children. Perhaps problems with child care are not severe enough to interfere with employee job satisfaction. Also, the JDI has major drawbacks: it is practical rather than technical (Landy, 1989). The JDI covers major categories but there are other areas that are not covered. In a given situation, some of these other areas might be more important. For example, employees may be either satisfied or dissatisfied with processes in the organization but the JDI does not examine this aspect of the job. Occasionally, supplementary questionnaires might be needed for measuring attitudes toward other aspects of the job not measured in the JDI (Lande, 1989) . The analyses also revealed that employees' 
satisfaction with child care, regardless of type of care, was related to absenteeism. The analyses showed that as parents' satisfaction with care increased, the number of absences reported decreased. This study supports Goff et al.'s (1990) finding that satisfaction with care was related to lower absenteeism. However, a significant relationship was not found between satisfaction with care and job satisfaction.

The final analysis compared differences between males and females on absenteeism. Previous research on child care and absenteeism has found that among parents, mothers have significantly higher absenteeism rates than fathers because of child care responsibilities (Englander-Golden \& Barton, 1983). Women often took more sick leave than men (Miller, 1984). The present analysis indicated that men and women did not differ significantly on either measure of absenteeism. Perhaps the sample size was too small to detect significant differences. However, a follow-up analysis indicated that women spend significantly more time on tasks related to child rearing than do men.

\section{LIMITATIONS AND IMPLICATIONS FOR FUTURE RESEARCH}

There are a number of methodological limitations to the present study. First, as in many field studies, there was nonrandom assignment of participants to 
conditions in the experimental design. Therefore, group differences could not be controlled. Furthermore, the number of subjects in each group was not equal. Some groups contained many subjects while others had very few subjects. Also, the sample size for this study was small $(N=86)$. Therefore, the power to detect significant differences across groups may not have been as strong as desired. For example, if the power of the test were increased then type of care and satisfaction with care may have had an effect on job satisfaction.

Another limitation of this study was that the sample of the university may not be the best sample to test the hypotheses. Employees within this organization enjoy more flexibility than traditional organizations with more structure, so these findings may not be generalizable.

Another limit of this study was that the parents in this sample were older parents. Therefore, their children may be capable of caring for themselves. The majority of parents in this study use self-care by child which is probably not a problem for children between the ages of 13-18. If the sample was larger, then the analyses should exclude children over the age of 13 . Also, information about disabled children was not considered in this study. Parents' satisfaction with care may be further complicated if their child was disabled. 
There are some Iimitations to the job satisfaction measure used in this study. Only the overall job satisfaction score was examined in the analyses. The measures of satisfaction with work, pay, promotions, supervision, and co-workers were not analyzed separately. If employees' satisfaction with supervision was examined separately, perhaps there may have been a relationship between job satisfaction and type of care. Employees who receive support from their supervisors concerning child care issues may have higher levels of job satisfaction. Also, job satisfaction may be positively affected by employer-supported child care (whether it's center or subsidy for care). Another possible reason for lack of effect on job satisfaction is that some parents may use a combination of types of care. This study examined only the primary type of child care arrangement that parents use. Some parents may use other forms of care not examined in this study which may have an affect on employee job satisfaction.

Further methodological problems may be related to the measures of absenteeism. Voluntary and involuntary absences were not assessed. Employees' self-report on absenteeism is a difficult criterion to measure in organizational research because of its unreliability. Some possible alternatives to self-report are measures of absenteeism in employee records or supervisory reports of 
absenteeism.

Another problem related to the absenteeism measure (during the last year) is the finding that employees using care by nonrelatives had significantly higher absences than all other groups. This result may be due to the high number of missing responses within this absence category. Many participants indicated that when asked to report the number of absences during the last year, they found the question repetitious or too difficult to remember and did not answer the question. Overall, the findings of this study have implications for the employer's role in child care. One implication is that there may be little benefit for employers to provide child care centers if quality care is available elsewhere. Satisfaction with care seems to play an important role in reducing absenteeism, thus, employers could help provide child care information or referral services for those parents who cannot find satisfactory care.

In the present study, on-site child care facilities were not represented as a separate condition. It is suggested that future researchers examine such on-site child care centers as another type of child care arrangement in their analyses. Furthermore, there may be other benefits to quality child care in the work-place which might alter satisfaction ratings, such as 
convenience, access to child at breaks and lunches, ability to visit care site, resulting in on-site centers differently affecting both satisfaction with child care and job satisfaction. Finally, future researchers should examine a more structured organizational sample which may increase the generalizability of the study's results. 
REFERENCES

Auerbach, J. D. (1990). Employer-supported child care as a women-responsive policy. Journal of Family Issues, 11, 384-400.

Auerbach, J. D. (1988). In the Business of Child Care: Employer Initiatives and Working Women. New York: Praeger Publishers.

Balzer, W. K., \& Smith, P. C. (1990). User's Manual for the Job Descriptive Index (JDI) and the Job in General (JIG) Scales. Bowling Green state University.

Canon, B. (April 1978). Child care where you work. Ms., 83-86.

Cohen, S., \& Wills, T. A. (1985). Stress, social support and the buffering hypothesis. Psychological Bulletin, 98, 310-357.

Emlen, A. C., \& Koren, P. E. (1984). Hard to Find and Difficult to Manage: The Effects of Child Care in the Workplace. Portland, OR: Regional Research Institute for Human Services.

Emlen, A. C., Koren, P. E., \& Yoakum, K. S. (1990) . 1990 dependent care survey: 15 employers of Lane county, Oregon. Portland, OR: Arthur Emlen \& Associates, Inc., and Portland State University, Regional Research Institute for Human Services.

Englander-Golden, P., \& Barton, G. (1983). Sex differences in absence from work: $A$ reinterpretation. Psychology of Women Quarterly, 8 , 185-188.

Fernandez, J. P. (1986). Child Care and corporate productivity. Lexington, Massachusetts: D.C. Heath and Company.

Friedman, D. (1987). Family-supportive Policies: The Corporate Decision-making Process. New York: The Conference Board, Inc. 
Goff, S. J., Mount, M. K., \& Jamison, R. L. (1990). Employer supported child care, work/family conflict, and absenteeism: A field study. Personnel Psychology, 43, 793-809.

Goldberg, W. A., Greenberger, E., Koch-Jones, J., O'Neil, R., \& Hamill, S. (1989). Attractiveness of child care and related employer-supported benefits and policies to married and single parents. Child and youth Care Quarterly, 18, 23-37.

Greenberger, E., Goldberg, W. A., Hamill, S., O'Neil, R., \& Payne, C. K. (1989). Contributions of a supportive work environment to parents' well-being and orientation to work. American Journal of Community Psychology, 17, 755-783.

Greenblatt, B. (1977). Responsibility for Child Care. San Francisco, CA: Jossey-Bass.

Harrell, J., \& Ridley, C. (1975). Substitute child care, maternal employment and the quality of mother-child interaction. Journal of Marriage and the Family, 37, 556-564.

Hedges, J. N. (October 1977). Absence from work measuring the hours lost. Monthly Labor Review, 1623 .

Kerr, V. (1973). One step forward - two steps back: Child care's long American history. Child Care - Who

Cares? Foreign and Domestic Infant and Early Childhood Development Policies, 151-171. New York: Basic Books.

Klein, B. (1986). Missed work and lost hours, May 1985. Monthly Labor Review, 109, 26-30.

Kossek, E. E. (1990). Diversity in child care assistance needs: Employee problems, preferences, and workrelated outcomes. Personnel Psychology, 43, 769-791.

Lande, J. S., Scarr. S., \& Gunzenhauser, N. (1989) . Caring for Children: Challenge to America. Hillsdale, NJ: Erlbaum.

Landy, F. J. (1989). Psychology of Work Behavior. Pacific Grove, CA: Brooks/Cole Publishing Company.

Milkovich, G. T., \& Gomez, L. R. (1976). Day care and selected employee work behaviors. Academy of Management Journal, 19, 111-115. 
Miller, T. (1984). The effects of employer-sponsored child care on employee absenteeism, turnover, productivity, recruitment or job satisfaction: What is claimed and what is known. Personnel Psychology, 37, 277-289.

Neal, M. B., Chapman, N. J., Ingersoll-Dayton, B., \& Emlen, A. C. (1993). Balancing Work and Caregiving for Children, Adults, and Elders. Newbury Park, CA: Sage Publications, Inc.

Northcott, H. C. (1983). Who stays home? Working parents and sick children. International Journal of Women's Studies, $6,387-394$.

Pence, A. R., \& Goelman, H. (1991). The relationship of regulation, training, and motivations to quality of care in family day care. Child \& Youth care Forum, 20, 83-101.

Petersen, D., \& Massengill, D. (1988). Childcare programs benefit employers, too. Personnel, 65, 58-62.

Powell, D. R., \& Bollin, G. (1992). Dimensions of parentprovider relationships in family day care. In $D$. $L$. Peters \& A. R. Pence (Eds.), Family day care: Current research for informed public policy. New York, NY: Teachers College Press.

Presser, H., \& Baldwin, W. (1980). Child care as a constraint on employment: Prevalence, correlates, and bearing on the work and fertility nexus. American Journal of Sociology, 85, 1202-1213.

Ross, C. E., \& Mirowsky, J. (1988). Child care and emotional adjustment to wive's employment. Journal of Health and Social Behavior, 29, 127-138.

Ruderman, F. A. (1968). Child Care and Working Mothers. New York: Child Welfare League of America, Inc.

Ruopp, T., Travers, J., Glantz, F., \& Coelen, C. (1979). Children at the center: Summary findings and their implications (Vol. 1). Cambridge, MA: Abt.

Smith, P. C., Kendall, L. M. \& Hulin, C. L. (1969). The Measurement of Satisfaction in Work and Retirement. Chicago: Rand-McNally.

Steinfels, M. O. (1973). Who's Minding the Children? The History and Politics of Day Care in America. New York: Simon and Schuster. 
U.S. Bureau of the Census. (1982). Trends in Child Care Arrangements of Working Mothers. Current Populations Reports, Series P-23, No. 117. Washington, DC: U.S. Government Printing office.

U.S. Bureau of the Census. (1983). Child Care Arrangements of Working Mothers: June 1982. Current Populations Reports, Series P-23, No. 129. Washington, DC: U.S. Government Printing office.

U.S. Department of Labor, Employment and Training Division. (1977). Women and Work. $R$ and $D$ Monograph 46. Washington, DC: U.S. Government Printing office.

Youngblood, S. A, \& Chambers-Cook, K. (1984). Child care assistance can improve employee attitudes and behavior. Personnel Administrator, 29, 45-46, 93-95.

Zippo, M. (1980). Employer-sponsored child care comes of age. Personnel, 57, 45-48. 
APPENDIX A

PAPER AND PENCIL QUESTIONNAIRE 


\section{Employee Survey}

Plcase answer the following questions. Please either circle the most appropriate response or fill in the spaces provided.

1. Age: years

2. $S c x$ :

1. Male

2. Female

3. Marital status:

1. Single/divorced/widowed without dependent children

2. Single/divorced/widowed with dependent children for whom you are primarily responsible

3. Married without children

4. Married with dependent children for whom you are primarily responsible

5. Married with grown children

6. Unmarried couple living together with dependent children for whom you are primarily responsible

7. Unmarried couple living together without dependent children

4. Occupation:

1. Professional

2. Secretarial/Clerical

3. Technical/Paraprofessional

4. Skilled crafts

5. Service/Maintenance (e.g., food, health, cleaning, personal, protection, child care, etc.)

6. Other:

5. Job status:

1. Full-time

2. Part-time

6. Work schedule:

1. Standard full-time (e.g., 8.5)

2. Part-time

3. Flexible hours

4. Job sharing

5. Compressed work week

6. Oiher:

7. Length of service at Portland State University:

1. Less than 1 year

2. 1.5 years

3. 6-10 years

4. 11.15 years

5. 16 or morc years

8. The number of hours per week you usually work? hours

9. The number of days per week you usually work? days

10. In the past four weeks:

a. How many days have you missed work other than holidays?

b. How many times have you been late to work? times days

c. How many times have you left work early or left during the day?

d. While at work, how many times have you been interrupted (including telephone calls) to deal with family relatcd matters? iimes 
11. In the past ycar:

a. How many days have you missed work other than holidays? days

b. How many times have you been late to work? times

c. How many limes have you left work early or left during the day? times

d. While at work, how many times have you been interrupted (including tclephone calls) to deal with family related matiers? times

12. Is your spouse/pariner employed?

1. I don't have a spouse/partner

2. Yes, part-time, due to dependent care needs

3. Yes, part-time, by choice

4. Yes, full-time

5. No, by choice

6. No, due to other reasons (excluding dependent care)

7. No, due to dependent care needs

13. How many children do you have?

14. Do you have children (under age 18) living in your household?

1. Yes

2. No

If you have no children under 18 living in your household, please stop here and return the questionnaire in the envelope provided. Thank you for participating.

If you do have children under 18 living in your household, please continue.

15. What are the ages of the children in your household?

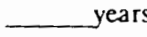
years, years, years, years, years, years, years, years, years, years

The following questions ask about the child care arrangements you currently use for any of the children living in your household.

16. Does an adult relative (age 18 or over) take care of any of the children while you are at work?

1. $\mathrm{Ye}$

2. No

IF YES, please answer all of the questions below. IF NO, please proceed to Question 17.

Is this person?

1. Your spouse or partner

2. Your older child, 18 or older

3. Grandparent

4. Other adult relative

What are the ages of the children cared for by this adult relative? years, years, years, years, years

How long have you used this child care arrangement? years months

While you arc away at work, how many hours a week do you use this arrangement? hours 
With regard to this child care arrangement, how satisfied are you with the following? Please circle the appropriate response.

$$
\begin{aligned}
& 1=\text { not at all satisfied } \\
& 2=\text { not very satisfied } \\
& 3=\text { satisfied } \\
& 4=\text { very satisfied }
\end{aligned}
$$

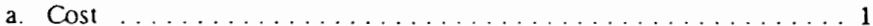

b. Hours available..

c. Location of child care 10 he

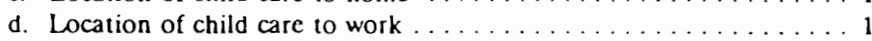

e. Physical appearance of environment ............... 1

c. Center activities and curriculum ..................

g. Overall quality of child care $\ldots \ldots \ldots \ldots \ldots \ldots \ldots \ldots \ldots$

h. Health, safety, and security precautions $\ldots \ldots \ldots \ldots \ldots \ldots$

i. Attention the child(ren) receives $\ldots \ldots \ldots \ldots \ldots \ldots \ldots$

j. Parental relationship with child care provider $\ldots \ldots \ldots \ldots \ldots \ldots 1$

k. Other, please specify

$\begin{array}{lll}2 & 3 & 4 \\ 2 & 3 & 4 \\ 2 & 3 & 4 \\ 2 & 3 & 4 \\ 2 & 3 & 4 \\ 2 & 3 & 4 \\ 2 & 3 & 4 \\ 2 & 3 & 4 \\ 2 & 3 & 4 \\ 2 & 3 & 4 \\ 2 & 3 & 4\end{array}$

17. Do you have children who look after themselves (under age 18) while you are at work?

1. Yes

2. No

IF YES, please answer all of the questions below. IF NO, please proceed to Question 18.

What are the ages of the children who care for themselves? years, years, years, years, years

How long have you used this child care arrangement? years months

While you are away at work, how many hours a week do you use this arrangement? hours

With regard to this child care arrangement, how satisfied are you with the following? Please circle the appropriate rcsponse.

$$
\begin{aligned}
& 1=\text { not at all satisfied } \\
& 2=\text { not very satisfied } \\
& 3=\text { satisfied } \\
& 4=\text { very satisfied }
\end{aligned}
$$

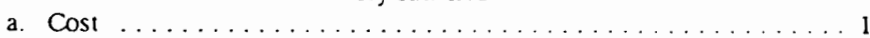

b. Hours available $\ldots \ldots \ldots \ldots \ldots \ldots \ldots \ldots \ldots \ldots \ldots \ldots$

c. Location of child care to home ..................

d. Location of child care to work ....................

e. Physica! appearance of environment .................

f. Center activities and curriculum . . . . . . . . . . . . . . .

g. Overall quality of child care .....................

h. Health, safety, and security precautions .............

i. Attention the child(ren) receives $\ldots \ldots \ldots \ldots \ldots \ldots \ldots$

Parental relationship with child care provider

k. Other, please specify

$\begin{array}{lll}2 & 3 & 4 \\ 2 & 3 & 4 \\ 2 & 3 & 4 \\ 2 & 3 & 4 \\ 2 & 3 & 4 \\ 2 & 3 & 4 \\ 2 & 3 & 4 \\ 2 & 3 & 4 \\ 2 & 3 & 4 \\ 2 & 3 & 4 \\ 2 & 3 & 4\end{array}$

18. Do you have children who are cared for by an older brother or sister (under age 18) whilc you are at work?

1. Yes

2. No

IF YES, please answer all of the questions below. IF NO, please proceed to Question 19.

What are the ages of the children who are looked after by an older brother or sister (under age 18)? years, years, years, years, ycars 

years monihs

While you are away at work, how many hours a week do you use this arrangement? hours

With regard to this child care arrangement, how satisfied are you with the following? Please circle the appropriate response.

$$
\begin{aligned}
& 1=\text { not at all satisfied } \\
& 2=\text { not very satisfied } \\
& 3=\text { satisfied } \\
& 4=\text { very satisfied }
\end{aligned}
$$

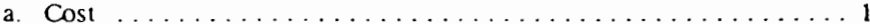

b. Hours available $\ldots \ldots \ldots \ldots \ldots \ldots \ldots \ldots \ldots \ldots \ldots$

c. Location of child care to home ..................

d. Location of child care to work .................. 1

e. Physical appearance of environment ...............

f. Center activities and curriculum . . . . . . . . . . . . . . 1

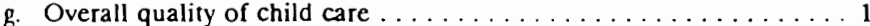

h. Health, safety, and security precautions .............

i. Attention the child $(r e n)$ receives $\ldots \ldots \ldots \ldots \ldots \ldots \ldots$

j. Parental relationship with child care provider $\ldots \ldots \ldots \ldots$

k. Other, please specify

$\begin{array}{lll}2 & 3 & 4 \\ 2 & 3 & 4 \\ 2 & 3 & 4 \\ 2 & 3 & 4 \\ 2 & 3 & 4 \\ 2 & 3 & 4 \\ 2 & 3 & 4 \\ 2 & 3 & 4 \\ 2 & 3 & 4 \\ 2 & 3 & 4 \\ 2 & 3 & 4\end{array}$

19. Does someone other than a relative care for any of the children in your home or in someone else's home?

1. Yes

2. No

IF YES, please answer all of the questions below. IF NO, please proceed to Question 20.

What are the ages of the children who are cared for by someone other than a relative? years, years, years, years, years

How long have you used this arrangement? years months

While you are away at work, how many hours a week do you use this arrangement? hours

With regard to this child care arrangement, how satisfied are you with the following? Please circle the appropriate response.

$$
\begin{aligned}
& 1=\text { not at all satisfied } \\
& 2=\text { not very satisfied } \\
& 3=\text { satisfied } \\
& 4=\text { very satisfied }
\end{aligned}
$$

a. Cost ...............................

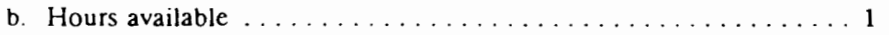

c. Location of child care to home ..................

d. Location of child care to work .................. I

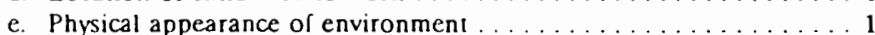

I. Center activities and curriculum .................

g. Overall quality of child care $\ldots \ldots \ldots \ldots \ldots \ldots \ldots \ldots \ldots$

h. Health, safety, and security precautions $\ldots \ldots \ldots \ldots \ldots \ldots$

i. Altention the child (ren) receives $\ldots \ldots \ldots \ldots \ldots \ldots \ldots \ldots \ldots$

j. Parental relationship with child care provider

k. Other, please specify

$\begin{array}{lll}2 & 3 & 4 \\ 2 & 3 & 4 \\ 2 & 3 & 4 \\ 2 & 3 & 4 \\ 2 & 3 & 4 \\ 2 & 3 & 4 \\ 2 & 3 & 4 \\ 2 & 3 & 4 \\ 2 & 3 & 4 \\ 2 & 3 & 4 \\ 2 & 3 & 4\end{array}$

20. Are any of the children cared for in a child care center? (By "child care center" we mean day care centers, nursery schools, and before and after-school facilities, but not public kindergarien or elementary school.)

1. Yes

2. No 
IF YES, please answer all of the questions below. IF NO, please proceed to Question 21.

What are the ages of the children cared for in the center or school-based program?

How long have you used this arrangement?
While you are away at work, how many hours a
With regard to this child care arrangement, how
response.
\[ \begin{aligned} 1 & =\text { not at all satisfied } \\ 2 & =\text { not very satisfied } \\ 3 & =\text { satisfied } \\ 4 & =\text { very satisfied }\end{aligned} \]

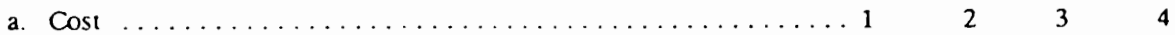

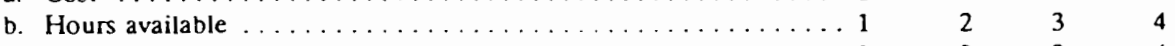

c. Location of child care to home ..................

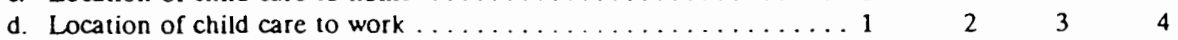

e. Physical appearance of environment ................

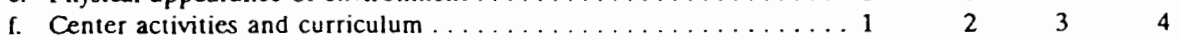

g. Overall quality of child care ...................

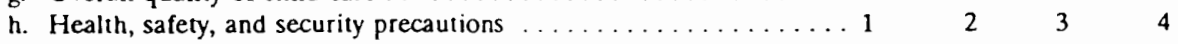

i. Attention the child(ren) receives .................

j. Parental relationship with child care provider ............

k. Other, please specify ___ $\begin{array}{lllll}1 & 2 & 3 & 4\end{array}$

21. When your child is sick, do you have a child care arrangement that allows you to continue working? Please circle the one response that best describes your situation.

1. Yes, my child care provider cares for ill children

2. Yes, I have made arrangements for my child in the event he/she becomes ill so that I need not miss work

3. Yes, other (explain)

4. No, when my child is ill I must use work time to find alternative arrangements

5. No, when my child is ill I must stay home from work

6. No, other (explain)

22. In your household, who spends the most time on tasks related to child rearing? Please circle the one response that best describes your situation.

1. My spouse/partner has sole responsibility for tasks related to child rearing

2. My spouse/partner spends much more time than I do on tasks related to child rearing

3. My spouse/partner spends slightly more time than I do on tasks related to child rearing

4. My spouse/partner and I spend about equal time on tasks related to child rearing

5. I spend slightly more time on tasks related to child rearing

6. I spend much more time on tasks related to child rearing

7. I have sole responsibility for tasks related to child rearing

23. Other than you or your spouse/partner staying home with your child, what is your preferred form of child carc?

1. Adult (over 18) member of the household

2. Older brother/sister

3. Someone who comes to your home

4. Someone in whose home you leave your child (Family Carc)

5. Day Care Center

6. Other (PLEASE SPECIFY) 
24. Picase indicate the extent to which you agree with the following statements. Circle the appropriate response.

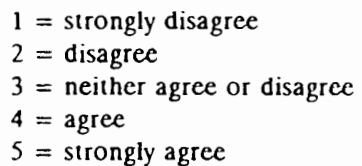

a. My work schedule often conflicts with my

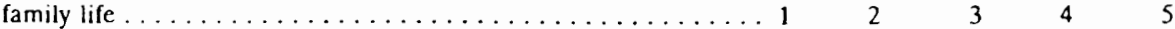

b. After work, I come home too tired to do some of the things l'd like to do ................. 1 $24 \quad 3 \quad 4 \quad 4$

c. On the job, I have so much work to do

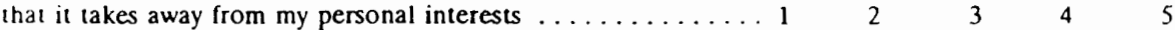

d. My family dislikes how often I am

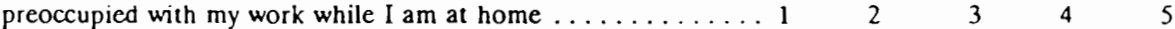

c. Because my work is demanding, at times I

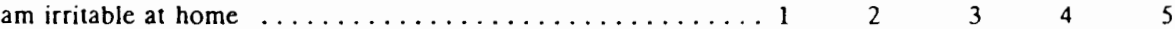

1. The demands of my job make it difficult to

g. My work takes up time that l'd like to spend with my family

h. My job makes it difficult to be the kind of spouse or parent l'd like to be

1. My family life ofien conflicts with my work schedule ........................

1. Due to family responsibilities, I lack the energy to perform my job well $\ldots \ldots \ldots \ldots \ldots \ldots \ldots \ldots 1$

k. I have so much to do at home that it takes away from my interest in work $\ldots \ldots \ldots \ldots \ldots \ldots \ldots$

1. My employer dislikes how often I am preoccupied with my family responsibilities while I am at work .........

$m$. Because my family responsibilities are so demanding, I am sometimes ineffective at work ........ 1

$n$. The demands of my family responsibilities make it difficult to concentrate on my work ........... 1 2

o. My family responsibilities take up time that I would like to spend at work .............. I 2

p. My family responsibilities make it difficult to be the kind of employee I'd like to be $\ldots \ldots \ldots \ldots \ldots 1$

q. I feel guilty about leaving my child(ren) in the care of others ................................ 1. At times during the work day my attention
shifts to concern about my child's welfare

25. How seriously have you considered leaving your job because of child care problems?

1. Very seriously

2. Somewhat seriously

3. Nol very seriously

4. Nol at all seriously

26. How often have you changed child care arrangements in the past year? times 
Think of the work you do at present How well does each of the following words or phrases describc your work? In the blank beside each word or phrase below, write

Y for "Yes" if it describes your work

N_for "No" if it does NOT describe it

? if you cannor decide

\section{WORK ON PRESENT JOB}

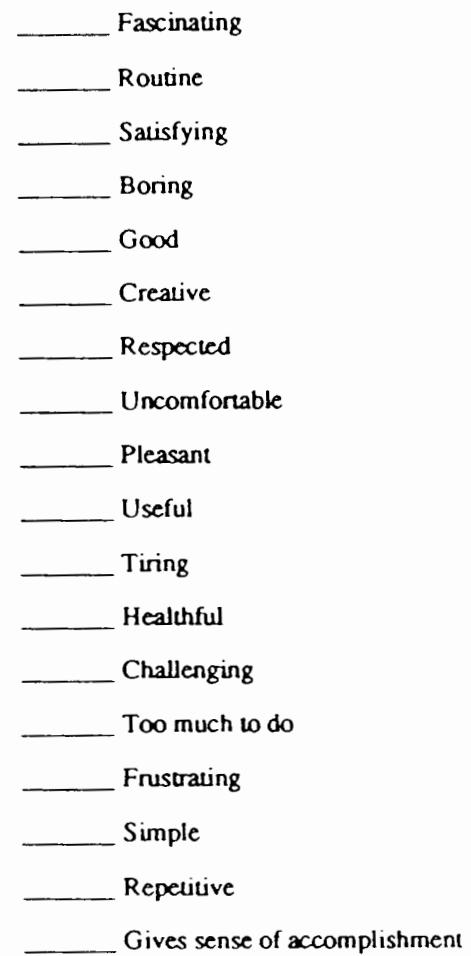

Think of the pay you ged now. How well does each of the following words or phrases describe your present pay? In the blank beside each word or phrase below, write

_. Y for "Yes" if it describes your pay

$N$ for "No" if il does NOT describe it

? if you cannor docide

\section{PRESENT PAY}

Income adequate for normal expenses Fair

Barely live on income Bad

Income provides luxuries Insecure

Less than I deserve Well paid

Underpaid 
Think of the opporwnities for promotion that you have now. How well doce each of the following words or phrases describe these? In the blank beside each word or phrase below, write

Y for "Yes" if it describes your opportunities for promocion

$\mathrm{N}$ for "No" if it does NOT describe them

? if you cannot decide

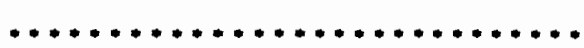

OPPORTUNITIES FOR PROMOTION

Good opportunities for promocion

Opportunities somewhat limited

Promotion on ability

Dead-end job

Good chance for promotion

Unfair promocion policy

Infrequent promotions

Regular promotions

Fairly good chance for promotion
Think of the kind of supervision that you get on your job. How well does each of the following words or phrases describe this? In the blank beside each word or phrase below, write

$Y$ for "Yes" if it describes the supervision you ger on your job

$\mathrm{N}$ for "No" if il does NOT describe it

? if you cannor decide

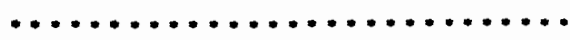

SUPER VISION

Asks my advice

Hard to please

Impolite

Praises good work

Tactul

Influential

Up-to-date

Doesn't supervise enough

Has favorites

Tells me where I stand

Annoying

Stubbom

Knows job well

Bad

Intelligent

Poor planner

Around when noeded

Lazy 
Think of the majority of the people that you work with now or the people you meet in connection with your work. How well does each of the following words or phrases describe these people? In the blank beside cach word or phrase below, write

Y for "Yes" if it describes the people you work with

$\mathrm{N}$ for "No" if it does NOT describe them

? if you cannol decide

\section{CO-WORKERS (PEOPLE)}

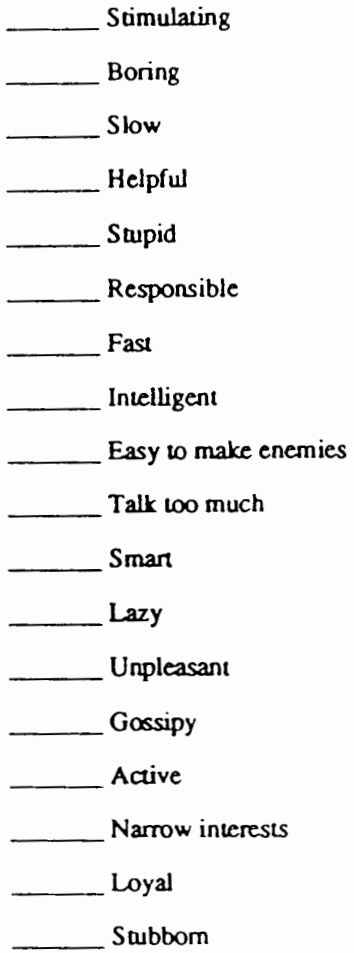

Think of your job in gcncral All in all, what is it like most of the time? In the blank beside each word or phrase below, wrile

$$
\begin{aligned}
& \mathrm{Y} \text { _ for "Yes" if it describes your job } \\
& \mathrm{N} \text { for "No" if it does NOT describe it } \\
& ? \quad \text { if you cannot decide }
\end{aligned}
$$

\section{JOB IN GENERAL}

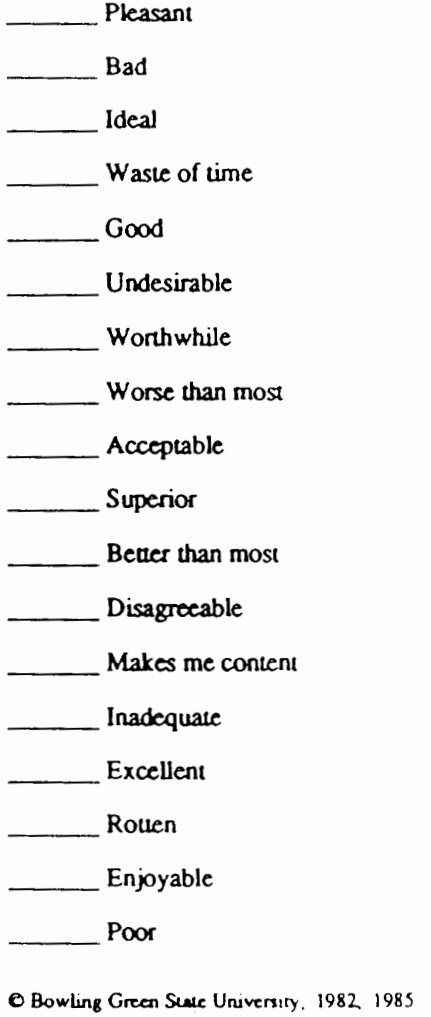

Please return the questionnaire in the envelope provided.

Thank you for participating. 